\title{
Relative importance of environmental factors in determining physiological differences between two populations of mussels (Mytilus edulis)
}

\author{
J. Widdows, P. Donkin, P. N. Salkeld, J. J. Cleary, D. M. Lowe, S. V. Evans and \\ P. E. Thomson
}

Institute for Marine Environmental Research, Prospect Place, The Hoe, Plymouth PL1 3DH, England

\begin{abstract}
Mussels Mytilus edulis were reciprocally transplanted between 2 environments, the Tamar estuary (south-west England) and Swansea dock (south Wales). Physiological and cellular responses of native and transplanted mussels at each site were measured at the beginning (January, 1978 ) and after 7, 16 and 23 wk. Tissue concentrations of some metals ( $\mathrm{Cd}, \mathrm{Cu}, \mathrm{Fe}, \mathrm{Pb}, \mathrm{Zn})$ and hydrocarbons were determined. Changes in metal and hydrocarbon concentrations in the tissues were complex and a function of specific contaminant, tissue and time. There were marked physiological differences between the 2 native populations but transplanted mussels acclimatized to their new environments within 2 mo. This suggested that the measured physiological differences (clearance, respiration and excretion rates, absorption efficiency, $\mathrm{O}: \mathrm{N}$ and scope for growth) were largely determined by environmental rather than genotypic factors.
\end{abstract}

\section{INTRODUCTION}

Bayne and Widdows (1978) and Bayne et al. (1979) recorded marked differences in the responses of mussels Mytilus edulis from different populations to environmental changes. This was largely interpreted in terms of environmental conditions pertinent to those populations. In such circumstances, however, an unknown proportion of the observed difference may be due to genetic differences (Koehn, 1978; Freeman and Dickie, 1979).

In this study we examine the extent to which recorded population differences may be environmentally induced (phenotypic adaptation) rather than inherited characteristics of the population (genotypic adaptation). This was investigated by means of a reciprocal transplant experiment between 2 physiologically and morphologically distinct mussel populations living in different environments. The biological responses (viz. reproductive condition, respiration, clearance rate, absorption efficiency, excretion rate, oxygen to nitrogen ratio and 'scope for growth') were determined for both native and transplanted groups of mussels at each site. In addition to measuring the major natural environmental variables such as temperature, salinity and suspended particulates, the tissue concentrations of some environmental contaminants were determined in order to provide information on their long-term accumulation and depuration under natural field conditions and to assess whether these contaminants were likely to be important factors contributing to measurable changes in the physiological condition of mussels.

\section{MATERIAL AND METHODS}

Two mussel populations were chosen on the basis of differences in their environments as well as measurable physiological and morphological differences. One population was located in the Tamar estuary in southwest England and the other in Swansea docks, south Wales (Fig. 1). The Tamar population was littoral and estuarine, occurring on a gravel bank at the confluence of the Lynher and Tamar rivers; the Swansea dock population was sub-littoral with the mussels attached to pier supports. The Tamar population conforms to the Mytilus edulis genotype, but the Swansea dock population may be intermediate between the $M$. edulis and M. galloprovincialis genotypes (Skibinski and Beardmore, 1979; Skibinski et al., 1978). 


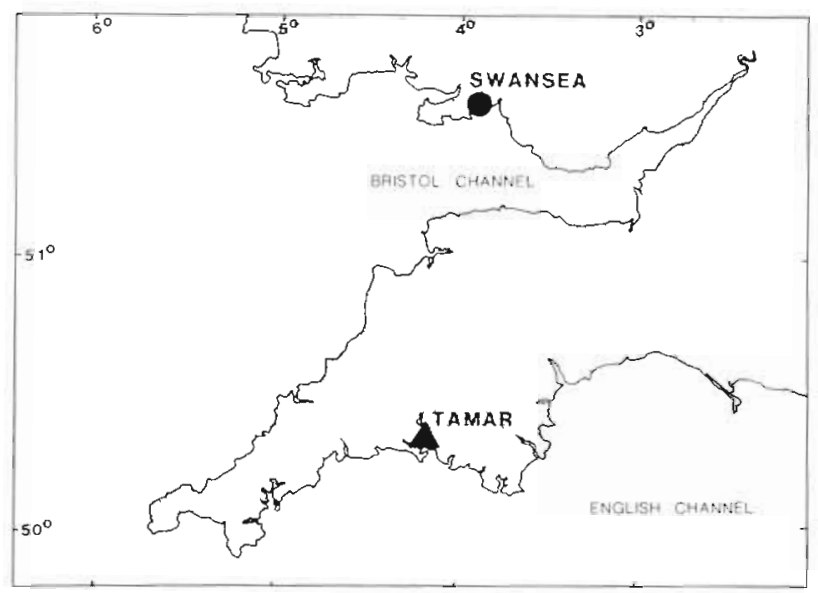

Fig. 1. Location of Tamar estuary in south-west England and Swansea docks in south Wales

\section{Transplanting of mussels between sites}

Mussels at Swansea were collected by divers and 400 individuals (referred to as Swansea natives or SN) were placed in one half of each of 4 paired cages. The other half of each cage contained 400 mussels (referred to as Tamar $\rightarrow$ Swansea transplants or $T \rightarrow$ S) collected from the Tamar population at low-water spring-tide level. The cages were then placed sub-littorally in Swansea docks.

At the Tamar site 4 similar paired cages, each containing 400 mussels from the Tamar population (Tamar natives or $\mathrm{TN}$ ) and 400 mussels transplanted from the Swansea population (Swansea $\rightarrow$ Tamar transplants or $\mathrm{S} \rightarrow \mathrm{T}$ ), were placed at low-water spring tide level. The cages were constructed of strong $1 \mathrm{~cm}^{2}$ wire mesh coated with plastic. Mussels were held out of water in a moist environment for $24 \mathrm{~h}$ during transportation between the 2 sites. In order to subject the 4 experimental groups of mussels to identical treatments, the native mussels from both sites were also air-exposed for $24 \mathrm{~h}$ before placing them in the cages. Furthermore, all mussels were cleaned of epibionts at the beginning of the experiment and again prior to the measurement of physiological responses.

Mussels were transplanted and caged at both sites between January 6th and 13th 1978, and subsequent visits were made at approximately 2 mo intervals (February 27th - March 9th, April 25th - May 4th, and June 13th - June 20th, 1978).

\section{Seawater measurements}

During each site visit temperature, salinity, and the concentrations of total seston and particulate organic matter (POM) were measured. Particulate material was sampled by filtering a known volume of seawater through a washed, ashed and pre-weighed glass-fibre filter. The salts were washed out of the filter with $3 \%$ ammonium formate, the filter dried at $100^{\circ} \mathrm{C}$ and weighed to calculate total seston $\left(\mathrm{mg} \mathrm{l}^{-1}\right.$ ). The filter was then ashed at $450^{\circ} \mathrm{C}$ and re-weighed in order to calculate the weight of material combusted; this value is referred to as the weight of particulate organic matter.

\section{Biological measurements}

The morphological difference between the 2 native mussel populations was measured by determining shell length and internal volume of shells over a size range of 50 individuals.

Stereological assessment of the reproductive tissue (mantle) was carried out on tissue sections of 5 mussels from each experimental group and the proportion of developing gametes, ripe gametes, evacuated follicles and adipogranular cells was expressed as a percentage of total volume (Lowe et al., 1982). Changes in the actual mass of ripe or developing gametes per 'standard mussel of lg dry-weight' were calculated by multiplying the percentage of total volume by the mass of mantle per $g$ of total dry tissue mass.

The physiological condition of the 4 experimental groups of mussels was determined, using a mobile laboratory, under conditions of ambient temperature, salinity, suspended particulates and environmental contaminants. Physiological responses such as oxygen consumption, clearance (feeding) rate, food absorption efficiency and excretion rate were measured using the techniques described by Bayne et al. (1977), Bayne and Widdows (1978) and Widdows (1984). Rates of oxygen consumption by Mytilus edulis were determined by isolating the respirometer $(500 \mathrm{ml})$ from flowing water for 45 to 60 min while monitoring the decline in oxygen tension in the chamber with a Radiometer oxygen electrode coupled to an amplifier and chart recorder. Clearance rate was measured in a flow-through system (150 $\mathrm{ml} \mathrm{min}^{-1}$ ) using a Coulter counter to determine the concentration of particles ( $>4 \mu \mathrm{m}$ spherical diameter) before and after the mussel chamber $(400 \mathrm{ml})$. Food absorption efficiency was estimated by the method of Conover (1966). The proportion of organic matter in the seston was compared with that in the faeces (and pseudofaeces where present). Rates of ammonia excretion were determined by placing individuals in $200 \mathrm{ml}$ of $0.2 \mu \mathrm{m}$ membrane-filtered seawater for $2 \mathrm{~h}$ and then analysing the water for ammonia using the phenolhypochlorite method of Solorzano (1969). On each sampling occasion the physiological variables were measured over a size range $(0.5$ to $2.0 \mathrm{~g}$ dry tissue 
mass) of 12 mussels and each physiological rate related to the mass of body tissue by the allometric equation:

$$
\mathrm{Y}=a \cdot \mathrm{X}^{b}
$$

where $\mathrm{Y}=$ physiological rate; $\mathrm{X}=$ body mass and $a$ and $b$ are fitted parameters. Physiological rates were then converted to a weight-specific rate for a $1 \mathrm{~g}$ mussel using the weight exponent (b).

\section{Chemical measurements}

Tissue analysis for metals

Ten mussels of similar body size $(1.34 \mathrm{~g} \pm 0.4 \mathrm{SD})$ were selected from each of the 4 experimental groups on each sampling occasion, transported to the laboratory and placed in artificial seawater ('Marine-Mix' by Wimex) $35 \%$ salinity and $10^{\circ} \mathrm{C}$ for a period of $18 \mathrm{~h}$ to allow defaecation of sediment from the gut. This procedure minimized contamination of tissues by metals associated with gut contents. A time-course study (48 h duration) demonstrated that $\mathrm{Al}, \mathrm{Si}$ and $\mathrm{Fe}$ concentrations in the mussel tissues declined rapidly (e.g. $90 \%$ of $\mathrm{Si}$ removed) during the initial $18 \mathrm{~h}$ without significantly altering the concentrations of other metals ( $\mathrm{Zn}$, $\mathrm{Cu}, \mathrm{Cd}, \mathrm{Pb})$. After allowing $18 \mathrm{~h}$ for evacuation of gut contents, mussels were dissected into kidney and 'remaining tissues'. Tissue from 10 individuals was bulked together to provide sufficient kidney for analysis, but each remaining tissue sample comprised material from 5 mussels. Samples were freeze-dried and homogenised prior to tissue digestion. Aliquots $(0.25 \mathrm{~g})$ of homogenized tissue were digested at $110^{\circ} \mathrm{C}$ for $1 \mathrm{~h}$ with Aristar (B.D.H.) nitric acid $(2 \mathrm{ml})$ in the sealed polytetrafluoroethylene liner of a decomposition vessel (Uniseal). The digest and washings were made up to 10 $\mathrm{ml}$ and the metals ( $\mathrm{Fe}, \mathrm{Zn}, \mathrm{Mn}, \mathrm{Cu}, \mathrm{Cd}$ and $\mathrm{Pb}$ ) analysed by flame atomic absorption spectrophometry.

Using the analytical procedures described above, percentage recoveries of metals added to tissue samples were $>90 \%$. Analysis of a 'standard tissue sample' of International Atomic Energy Authority Oyster homogenate (MA-M-1) yielded agreement with the standard values of within $\pm 2 \%$ for $\mathrm{Fe}, \mathrm{Mn}, \mathrm{Zn}$ and $\mathrm{Cu}$ which were present at relatively high concentrations, but agreement was less satisfactory for $\mathrm{Cd}(3.3 \pm 0.4$ compared with standard value of $\left.2.2 \pm 0.1 \mu \mathrm{g} \mathrm{g}^{-1}\right)$ and $\mathrm{Pb}$ (5.5 \pm 5.2 compared with standard value of $1.5 \pm$ $0.2 \mu \mathrm{g} \mathrm{g}^{-1}$ ) because concentrations were close to our limit of detection and below the concentrations measured in the mussel tissue samples.

Metal concentrations in marine organisms are known to be affected by body size/age (reviewed by Phillips, 1980), therefore metal concentrations in the tissues of Mytilus edulis were expressed as $\mu \mathrm{g}$ per $\mathrm{g}$ dry weight after correcting for minor differences in body mass using appropriate weight exponents established for each metal and each tissue over a size range of mussels from the Tamar population.

Tissue analysis for hydrocarbons

On each sampling occasion mussels $(15 \geq \mathrm{n} \geq 5)$ were collected from each of the 4 experimental groups and frozen prior to transportation to the laboratory. They were then thawed and the entire soft tissue from all the mussels in the sample was bulked and homogenized. The wet tissue $(6 \mathrm{~g})$ was saponified for $2 \mathrm{~h}$ and steam distilled for $2 \mathrm{~h}$ with $5 \mathrm{ml}$ of hexane and the product cleaned-up on an alumina column eluted with hexane (Widdows et al., 1982). The cleaned-up extract was analysed by UV spectrophotometry, quantified by measurement of the absorbance at $221 \mathrm{~nm}$, the wavelength of maximal absorbance of the naphthalene reference standard (c.f. Neff and Anderson, 1975 ) and by spectrofluorimetry (excitation $310 \mathrm{~nm}$. emission $374 \mathrm{~nm}$ ) quantified by reference to pyrene (Gordon et al., 1974; Zitko, 1975). To enable the results to be expressed in crude-oil equivalents (Hennig, 1979; Blackman and Law, 1980) the standards were calibrated against North Sea (Auk field) crude oil.

Extracts from 10 of the samples were also analysed, without further clean-up, by high performance liquid chromatography (HPLC) on a Partisil-10 PAC column (Whatman) using hexane as the mobile phase and fluorescence detection. The fluorometer excitation and emission wavelengths were set at $280 \mathrm{~nm}$ and $330 \mathrm{~nm}$ respectively to detect compounds with 2 aromatic rings (e.g. naphthalenes), or at $254 \mathrm{~nm}$ and $365 \mathrm{~nm}$, respectively to detect 3 ringed aromatics (e.g. phenanthrenes). Five of these extracts were also analysed directly by gas-liquid chromatography (GLC; Widdows et al., 1982). In order to obtain a more complete analysis of alkanes, 2 samples were steam-distilled for $16 \mathrm{~h}$ and the product resolved into alkanes and aromatics on silica, prior to GLC (Widdows et al, 1982). The aromatic fraction was further cleaned-up by PACHPLC.

Total lipid in the body tissues was determined by the method of Bligh and Dyer (1959).

\section{RESULTS}

\section{Environmental factors}

Temperature, salinity, seston and \% POM data for the 2 environments are illustrated in Fig. 2. The sea- 

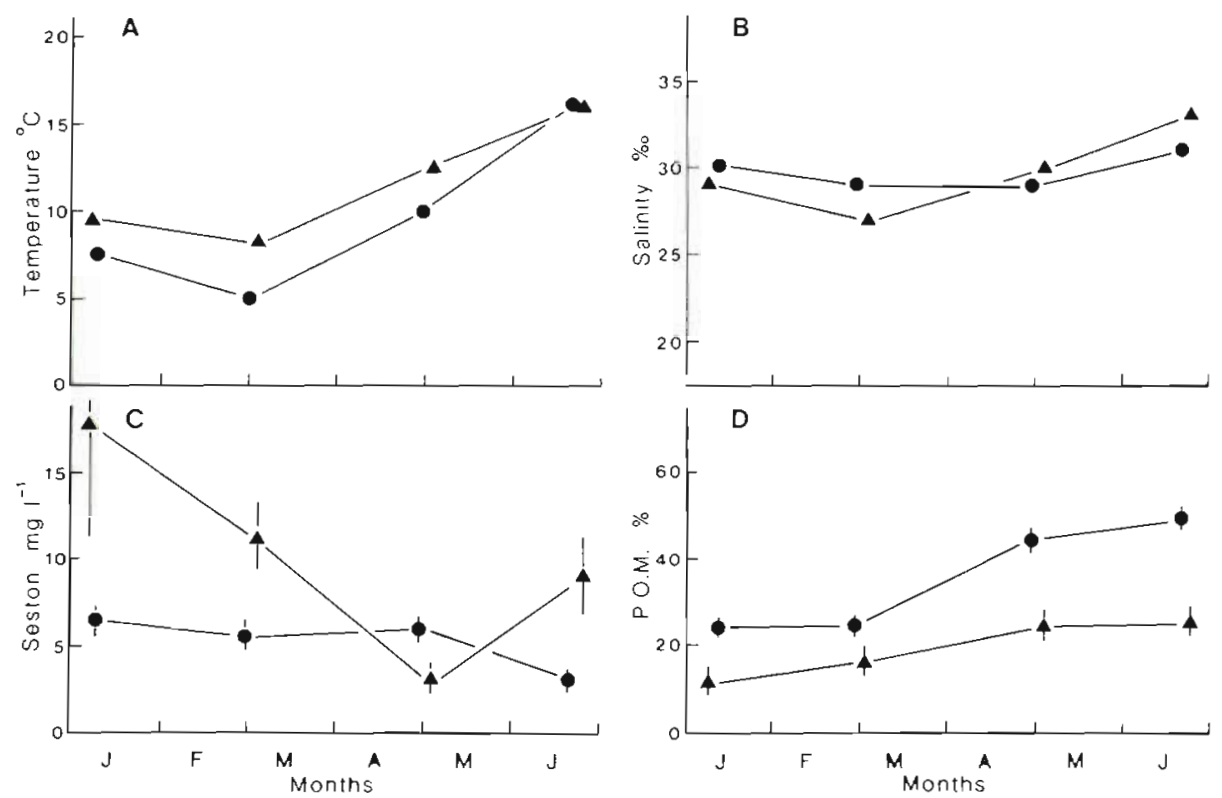

Fig. 2. Temporal changes in temperature $(A)$, salinity $(B)$, seston (C) and particulate organic matter (D). A Tamar estuary; - Swansea dock. Mean \pm S.E.

sonal change in temperature was greater at the Swansea site (Fig. 2A) whereas the seasonal amplitude in salinity (Fig. 2B) and seston (Fig. 2C) was greater in the Tamar. Seston concentrations were higher in the Tamar except during the April-May sampling period. The \% POM was independent of the seston concentration and was consistently higher in Swansea docks (Fig. 2D), presumably due to the lower silt concentration resulting from the reduced tidal-water movement at this site.

\section{Biological measurements}

$$
\text { Shell length - volume relation }
$$

The 2 native populations showed distinct morphological differences in terms of shell shape. Swansea mussels generally had a thicker shell, a larger posterior adductor muscle, a downturned anterior end to the shell, a flattening of the ventral shell surface and greater shell width. Some of these differences in the shell shape were quantified by relating internal volume of shells to shell length (Fig. 3). Covariance analysis demonstrated that the Swansea mussels had a significantly larger shell volume per unit length compared with the Tamar mussels $(\mathrm{P}<0.001)$.

\section{Gametogenic stage}

Stereological assessment of the development state of the storage and reproductive tissues (mantle) was carried out for the 4 experimental groups of mussels on each sampling occasion. Table 1 demonstrates the change in the amount of developing and ripe gametes and of evacuated follicles in the mantles of the four groups of mussels between January and June. The Tamar natives contained a relatively constant amount of developing and ripe gametes throughout the winterspring period which, together with the large variance about mean values, suggests a continual release of gametes by the population and the absence of a distinct spawning period, although the increase in evacuated follicles in early March indicates a major release of gametes at this time. The adipogranular cells (nutritive storage tissue) declined significantly between

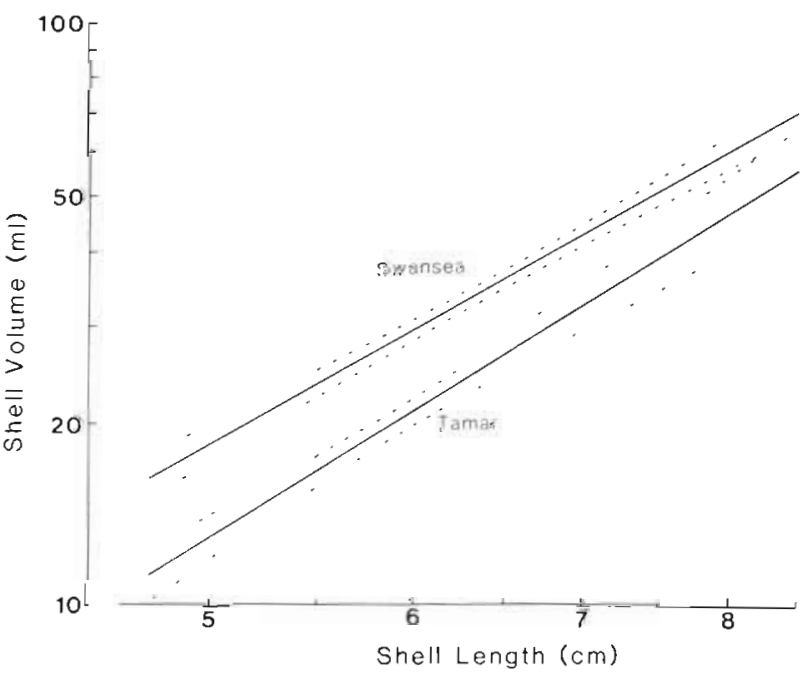

Fig. 3. Mytilus edulis. Relation between shell volume $(\mathrm{ml})$ and shell length $(\mathrm{cm})$. Regression line $\pm 95 \%$ Confidence limits. Tamar: $\log _{10}$ shell vol $=-0.774( \pm .167 \mathrm{SD})+\log _{10}$ shell length $\times 2.71( \pm .21 \mathrm{SD})$. Swansea: $\log _{10}$ shell $\mathrm{vol}=$ $-0.439( \pm 0.7 \mathrm{SD})+\log _{10}$ shell length $\times 2.45( \pm .13 \mathrm{SD})$ 
Table 1. Mytilus edulis. Gamete or cell mass (not including vesicular connective tissue and blood sinuses) expressed as mg in the mantle of a 'standard $1 \mathrm{~g}$ individual'. Mean \pm S.E. $(n=5)$. TN Tamar natives; SN Swansea natives; T $\rightarrow \mathrm{S}$ Tamar mussels transplanted to Swansea; $\mathrm{S} \rightarrow \mathrm{T}$ Swansea mussels transplanted to Tamar

\begin{tabular}{|c|c|c|c|c|c|c|c|}
\hline $\begin{array}{c}\text { Time } \\
\text { (weeks) }\end{array}$ & $\begin{array}{l}\text { Date } \\
(1978)\end{array}$ & $\begin{array}{l}\text { Experimental } \\
\text { group }\end{array}$ & $\begin{array}{l}\text { Developing } \\
\text { gametes }\end{array}$ & Ripe gametes & $\begin{array}{l}\text { Evacuated } \\
\text { follicles }\end{array}$ & $\begin{array}{l}\text { Adipogranular } \\
\text { cells }\end{array}$ & $\begin{array}{c}\text { Mantle as } \% \\
\text { of body wt }\end{array}$ \\
\hline 0 & 9.1 & TN & $25.73 \pm 9.65$ & $13.19 \pm 10.31$ & $6.34 \pm 1.64$ & $35.92 \pm 9.1$ & 15.17 \\
\hline 0 & 11.1 & SN & $42.29 \pm 6.68$ & $36.16 \pm 13.67$ & $2.23 \pm 1.43$ & $11.45 \pm 8.1$ & 15.9 \\
\hline 7 & 5. 3. & TN & $18.48 \pm 14.9$ & $26.38 \pm 26.38$ & $27.2 \pm 9.35$ & $17.45 \pm 15.16$ & 20.77 \\
\hline 7 & 28. 2. & SN & $66.08 \pm 14.7$ & $9.12 \pm 9.12$ & $17.75 \pm 5.75$ & $13.52 \pm 9.80$ & 16.90 \\
\hline 7 & 28.2. & $\mathrm{~T} \rightarrow \mathrm{S}$ & $63.19 \pm 19.54$ & $81.98 \pm 22.33$ & $3.30 \pm 3.30$ & $14.47 \pm 7.87$ & 25.58 \\
\hline 7 & 5.3. & $\mathrm{~S} \rightarrow \mathrm{T}$ & $6.15 \pm 2.27$ & $0.4 \pm 0.4$ & $7.89 \pm 3.08$ & $\overline{0}$ & 13.37 \\
\hline 16 & 4. 5 & TN & $16.26 \pm 7.14$ & $27.17 \pm 27.17$ & $7.34 \pm 2.58$ & $1.18 \pm 1.18$ & 19.83 \\
\hline 16 & 28.4 . & SN & $52.44 \pm 10.18$ & $43.02 \pm 8.51$ & $22.49 \pm 6.54$ & 0 & 15.2 \\
\hline 16 & 28.4 . & $\mathrm{T} \rightarrow \mathrm{S}$ & $34.13 \pm 6.95$ & $145.8 \pm 12.85$ & 0 & 0 & 21.07 \\
\hline 16 & 4. 5 & $\mathrm{~S} \rightarrow \mathrm{T}$ & $34.16 \pm 3.42$ & $25.09 \pm 17.9$ & $22.57 \pm 4.46$ & $1.34 \pm 0.89$ & 14.85 \\
\hline 23 & 18.6. & $\mathrm{TN}$ & $4.9 \pm 4.9$ & $24.06 \pm 14.9$ & $12.92 \pm 5.19$ & $15.4 \pm 15.4$ & 14.77 \\
\hline 23 & 15.6 . & SN & $18.63 \pm 9.32$ & $25.02 \pm 10.8$ & $13.34 \pm 7.65$ & $5.84 \pm 5.0$ & 13.9 \\
\hline 23 & 15. 6. & $\mathrm{~T} \rightarrow \mathrm{S}$ & $16.17 \pm 9.19$ & $60.76 \pm 25.87$ & $3.57 \pm 2.72$ & $25.19 \pm 19.1$ & 17.02 \\
\hline 23 & 18.6. & $\mathrm{~S} \rightarrow \mathrm{T}$ & $16.38 \pm 8.58$ & $12.68 \pm 6.7$ & $6.74 \pm 1.98$ & $1.58 \pm 1.32$ & 13.21 \\
\hline
\end{tabular}

January and May followed by a recovery in June. Swansea natives showed a more marked reproductive cycle with a peak in developing gametes in the late winter followed by a peak in ripe gametes in AprilMay. This cycle and the smaller variances about the mean values of developing and ripe gametes suggests a more synchronized period of gametogenesis and spawning in the Swansea natives. The amount of adipogranular cells in the mantle was low throughout the winter-spring period.

Mussels transplanted from the Tamar to Swansea showed a peak in developing gametes and a marked peak in ripe gametes in February-March. The seasonal change in adipogranular cells in the TN mussels was retained by the $\mathrm{T} \rightarrow \mathrm{S}$ mussels.

$\mathrm{S} \rightarrow \mathrm{T}$ mussels differed from the SN due to the reduction in developing gametes in February-March. However, the amount of adipogranular cells in the mantle remained very low and similar to the $S N$. These findings confirm the results of recent comparative studies of reproductive cycles in Mytilus edulis (Lowe, unpubl.); marked population differences in the amount and seasonal cycles of nutritive storage cells were found to be maintained following transplantation between populations living in different environments.

\section{Physiological measurements}

All physiological rates were corrected to a standard body size (1 g) which approximated the mean dry tissue weight $(1.038 \mathrm{~g})$ of mussels sampled from both populations.
Oxygen consumption. The weight-specific oxygen consumption $\left(\mathrm{VO}_{2}: \mathrm{ml} \mathrm{O}_{2} \mathrm{~g}^{-1} \mathrm{~h}^{-1}\right)$ increased with seasonal temperature between February and June (Fig. 4). There were no significant differences in the rates of oxygen uptake by the 4 groups of mussels, except during April-May when the mussels in the Tamar (TN and $\mathrm{S} \rightarrow \mathrm{T})$ had significantly higher rates $(\mathrm{P}<0.05)$ than those in Swansea docks.

Clearance rates. Native and transplanted mussels in the Tamar had significantly higher clearance rates than those in Swansea docks (Fig. 5). Within 7 wk of transplanting mussels between the 2 environments the

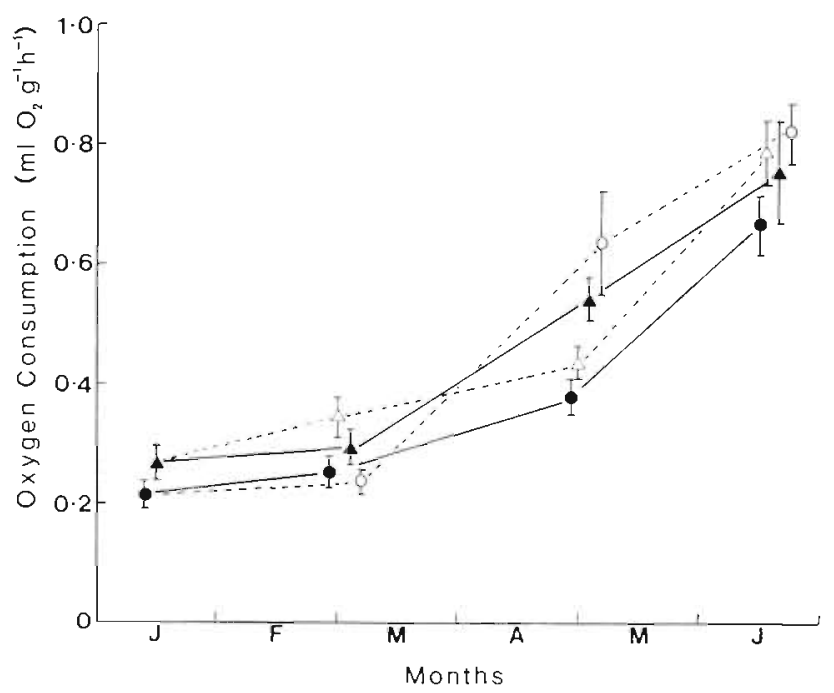

Fig. 4. Mytilus edulis. Rate of oxygen consumption of native and transplanted mussels. Mean \pm S.E. $\Delta$ Tamar natives; $\Delta$ Tamar $\rightarrow$ Swansea transplants; $\bullet$ Swansea natives, OSwansea $\rightarrow$ Tamar transplants 
clearance rates of $\mathrm{T} \rightarrow \mathrm{S}$ individuals had been reduced and clearance rates of $\mathrm{S} \rightarrow \mathrm{T}$ mussels had been increased to rates similar to those of the native individuals. However, between April and June the clearance rates of transplanted mussels did not show complete acclimatization to their new environments.

Absorption Efficiency. Food absorption efficiency was 1.5 to 2 fold higher in the $\mathrm{SN}$ and $\mathrm{T} \rightarrow \mathrm{S}$ mussels compared with the TN and $S \rightarrow T$ individuals (Fig. 6). The lower absorption efficiencies of mussels at the Tamar site were not related to either the spatial or temporal differences in seston concentration. In AprilMay the seston concentration declined to values below those found at the Swansea site (Fig. 2), but there was not a reciprocal change in the absorption efficiency of $\mathrm{TN}$ or $\mathrm{S} \rightarrow \mathrm{T}$ to values greater than $\mathrm{SN}$ or $\mathrm{T} \rightarrow \mathrm{S}$ mussels. The higher absorption efficiencies recorded for mussels at Swansea were due, in part, to the significantly lower clearance rates in the $\mathrm{SN}$ and $\mathrm{T} \rightarrow \mathrm{S}$ individuals. A reduced food intake is partially compensated by an increase in food absorption efficiency (Bayne et al., 1976a; Widdows, 1978a). In addition to the spatial differences in absorption efficiency there was also a temporal increase in the absorption efficiency of both native and transplanted mussels. This seasonal increase was not concomitant with a rise in temperature (Fig, 2) and was probably the result of a gradual improvement in the quality of POM during the spring and summer when algal productivity and biomass increase and a greater proportion of the POM is likely to be non-refractory and utilizable food mate-

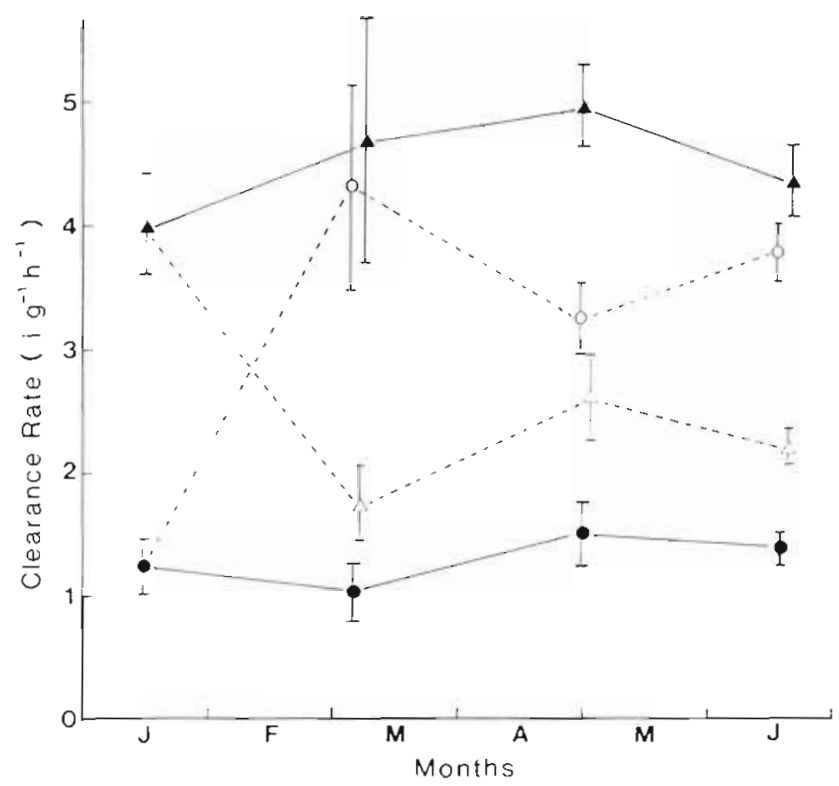

Fig. 5. Mytilus edulis. Clearance rate of native and transplanted mussels. Mean \pm S.E. A Tamar natives; $\triangle$ Tamar $\rightarrow$ Swansea transplants; - Swansea natives; $O$ Swansea $\rightarrow$ Tamar transplants

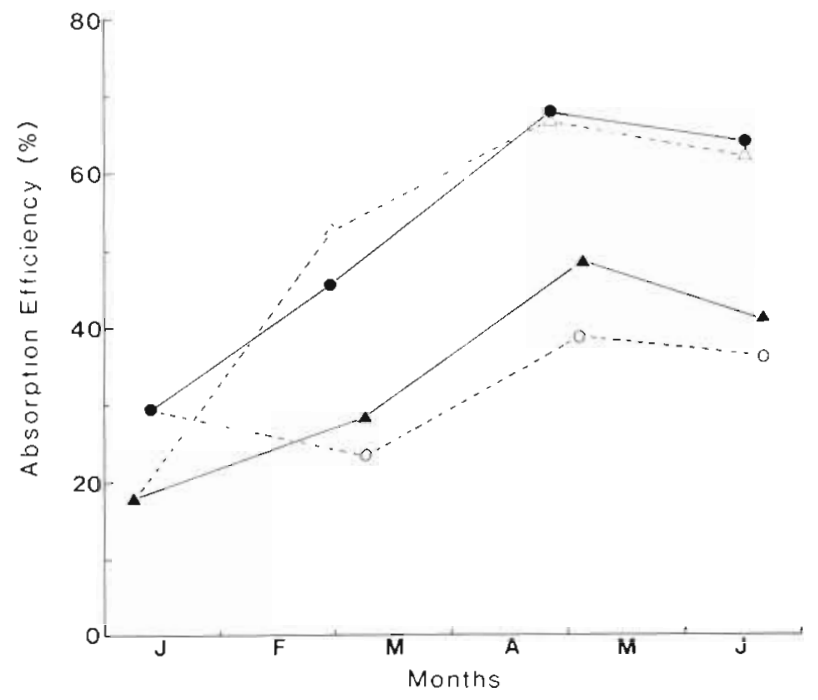

Fig. 6. Mytilus edulis. Food absorption efficiency of native and transplanted mussels $\Delta$ Tamar natives; $\triangle$ Tamar $\rightarrow$ Swansea transplants; $\bullet$ Swansea natives; OSwansea $\rightarrow$ Tamar transplants

rial (Widdows et al., 1979). Bayne and Widdows (1978) recorded a similar seasonal increase in the food absorption efficiency of mussels from two populations.

Ammonia Excretion. Temporal changes in the rate of ammonia excretion by mussels from Swansea (SN) were small in comparison with the marked changes $(\sim 10$ fold) in excretion rates of Tamar (TN) mussels which increased from $7 \mu \mathrm{NH}_{4}-\mathrm{N} \mathrm{g}^{-1} \mathrm{~h}^{-1}$ in January, when they were lower than SN, to a maximum of $65 \mu \mathrm{g} \mathrm{g}^{-1} \mathrm{~h}^{-1}$ in May (Fig. 7). The excretion rates of $\mathrm{T} \rightarrow \mathrm{S}$ mussels were not significantly different from the $\mathrm{SN}_{i}$ whereas the $\mathrm{S} \rightarrow \mathrm{T}$ mussels, although following similar temporal changes to the TN mussels, showed a less pronounced increase in excretion rate in early May.

$O: N$. The O:N or the ratio of oxygen consumed to nitrogen excreted in atomic equivalents indicates the proportion of protein relative to carbohydrate and lipid that is catabolized for energy metabolism (Corner and Cowey, 1968; Bayne, 1973). A relatively high rate of protein catabolism results in a low $\mathrm{O}: \mathrm{N}$ ratio which is generally indicative of a stressed condition (Bayne et al., 1976b; Widdows, 1978b). The results (Fig. 8) are consistent with the notion that the $\mathrm{O}: \mathrm{N}$ ratio provides an assessment of the nutritional/metabolic state of the animal, reflecting overall utilization of protein from both accumulated body reserves and available food. The O:N ratio for TN was initially high (>40) but rapidly declined to very low values $(\sim 10)$ in early May (Fig. 8) when the rate of $\mathrm{NH}_{4}-\mathrm{N}$ excretion was maximal (Fig. 7), the metabolic requirement was high (Fig. 4) and suspended particulates were low (Fig. 2C). O:N ratios for SN were initially low (13) and increased to 25 


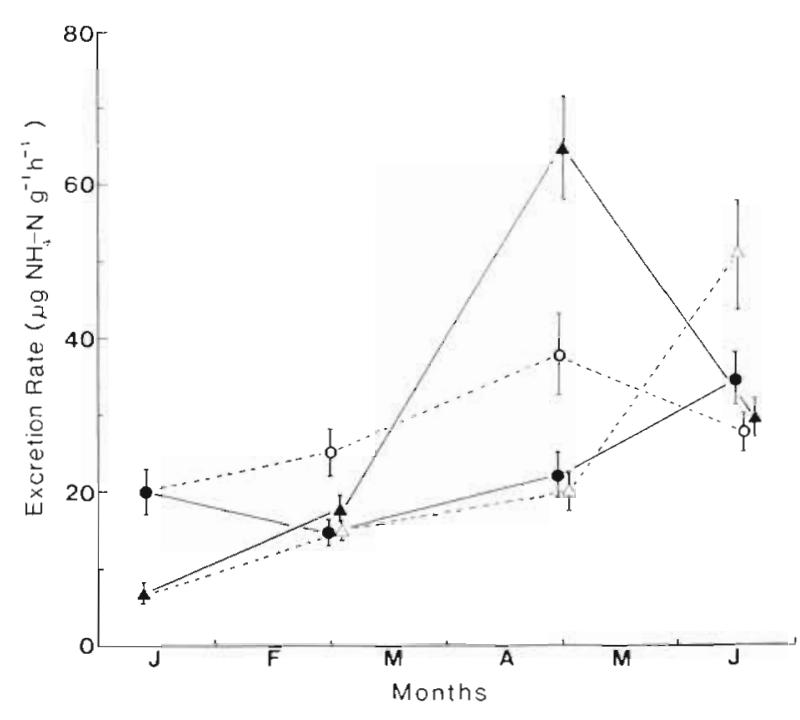

Fig. 7. Mytilus edulis. Excretion rates of native and transplanted mussels. Mean \pm S.E. $\triangle$ Tamar natives; $\Delta$ Tamar $\rightarrow$ Swansea transplants; $\bullet$ Swansea natives; OSwansea $\rightarrow$ Tamar transplants

by May - June, probably reflecting the generally lower but more stable seston concentrations.

Transplanted mussels had O:N ratios which followed the temporal pattern of the native mussels at each site. $\mathrm{T} \rightarrow \mathrm{S}$ transplants conformed to the more stable O:N values of the $\mathrm{SN}$ mussels, whereas the $\mathrm{S} \rightarrow \mathrm{T}$ mussels maintained a low $\mathrm{O}: \mathrm{N}$ ratio during the winter which then increased in the spring with the rise in $O: N$ of the TN mussels.

Scope for growth. The basic physiological responses were converted into energy equivalents $\left(\mathrm{J} \mathrm{h}^{-1}\right)$ and used in the balanced energy equation to calculate 'scope for growth' (Warren and Davis, 1967; Widdows, 1978b; Widdows et al., 1981). The balanced energy equation is as follows:

$$
\begin{gathered}
\mathrm{C}-\mathrm{F}=\mathrm{A}=\mathrm{R}+\mathrm{U}+\mathrm{P} \\
\mathrm{P}=\mathrm{A}-(\mathrm{R}+\mathrm{U})
\end{gathered}
$$$$
\text { or }
$$

where $\mathrm{C}=$ total consumption of food energy; $\mathrm{F}=$ faecal energy loss; $\mathrm{A}=$ energy absorbed from the food; $\mathrm{R}=$ respiratory heat loss; $\mathrm{U}=$ energy lost as excreta; $\mathrm{P}=$ energy available for production of both somatic tissues and gametes. Scope for growth $(\mathrm{P})$ is the energy available for somatic growth and gamete production after subtracting the energy losses due to respiration and excretion from the energy absorbed from the food.

In several studies, 'scope for growth' has been used to compare the functioning and performance of mussels from different environments (Bayne and Widdows, 1978; Bayne et al., 1979; Widdows et al., 1981). The results of the present study show a marked difference between the scope for growth of mussels living in the 2

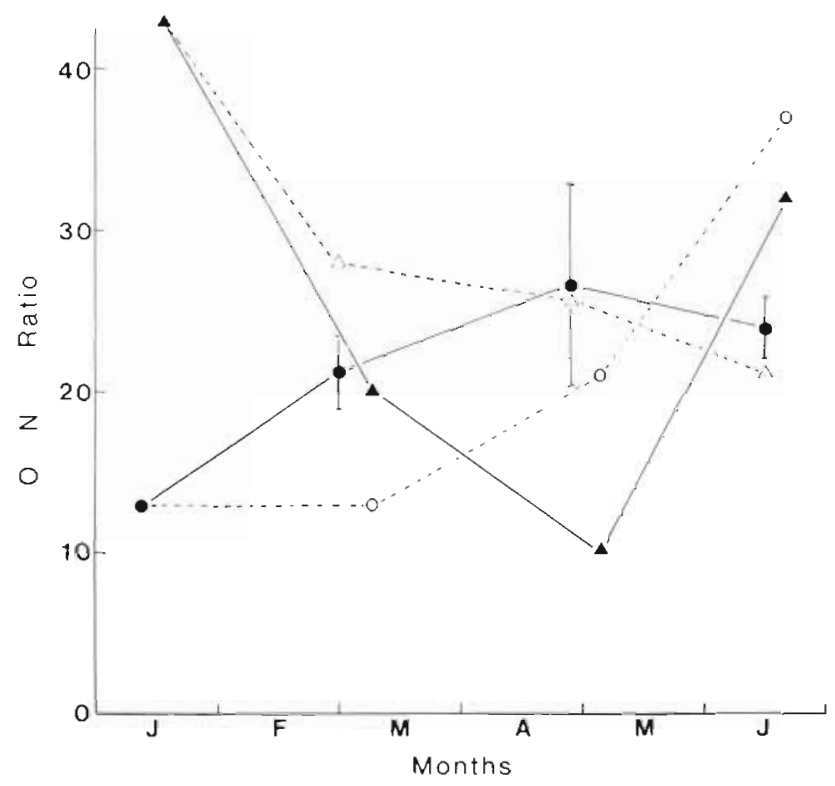

Fig. 8. Mytilus edulis. Ratio of oxygen consumed to ammonia nitrogen excreted for native and transplanted mussels. Mean \pm S.E. $\Delta$ Tamar natives; $\triangle$ Tamar $\rightarrow$ Swansea transplants; Swansea natives; $O$ Swansea $\rightarrow$ Tamar transplants

environments (Fig. 9). Values of scope for growth of both native and transplanted individuals in the Tamar estuary were higher than the mussels in Swansea docks ( $\mathrm{SN}$ and $\mathrm{T} \rightarrow \mathrm{S}$ ), except during late April when there was a major algal bloom in the docks which resulted in a high scope for growth. At this time of year both groups of mussels in the Tamar had a reduced scope for growth due to the lower seston and POM concentrations. In spite of the seasonal variation in the scope for growth of mussels at the Tamar and Swansea sites, the results show a distinct acclimatization by the transplanted mussels to their new environments.

Growth efficiencies provide a measure of the efficiency with which food is converted into body tissues (Bayne et al., 1976b; Widdows, 1978b; Widdows et al., 1981). Net growth efficiency $\left(K_{2}\right)$ or the growth per unit of the absorbed energy, was calculated from the measured physiological responses:

$$
K_{2}=\frac{A-(R+U)}{A}
$$

Table 2 shows the \% net growth efficiencies of Mytilus edulis at the 2 sites during the course of the field experiment. Mussels in the Tamar had higher growth efficiencies than those in Swansea docks, except during the late-April algal bloom. The data also demonstrate that at each site mussels originating from the Tamar (TN and $\mathrm{T} \rightarrow \mathrm{S}$ ) were functioning more efficiently than the mussels from the Swansea population $(\mathrm{SN}$ and $\mathrm{S} \rightarrow \mathrm{T}$ ). 


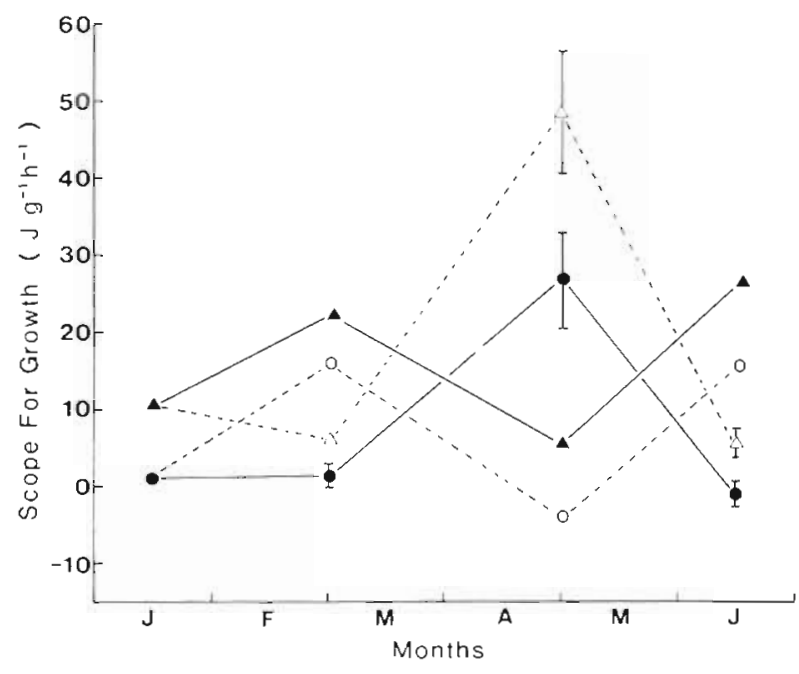

Fig. 9. Mytilus edulis. Scope for growth of native and transplanted mussels. Mean $\pm \mathrm{S}$.E. (standard error was estimated when pnysiological measurements were carried out on the same set of individuals). A Tamar natives; $\triangle$ Tamar $\rightarrow$ Swansea transplants; $\bullet$ Swansea natives; O Swansea $\rightarrow$ Tamar transplants

\section{Chemical measurements}

Metal concentrations in tissues

The results summarized in Table 3 and Fig. 10, 11 and 12 , indicate that several factors were responsible for determining the concentrations of metals in the tissues of Mytilus edulis living in the Tamar estuary and Swansea docks. Metal concentrations were partly a function of the type of tissue, the environment and the time spent in that environment. The data, when expressed in terms of metal content or body burden ( $\mu \mathrm{g}$ individual $^{-1}$ ) showed similar spatial and temporal differences as the metal concentration data $\left(\mu \mathrm{g} \mathrm{g}^{-1}\right.$ dry weight) because there were no marked changes in the mean body weight of the mussels during the course of the experiment.

Tissue differences. Two tissues - kidney and 'remaining tissues' - were analysed for $\mathrm{Cd}, \mathrm{Cu}, \mathrm{Fe}, \mathrm{Pb}$ and $\mathrm{Zn}$. The metals accumulated by the kidney reached high concentrations relative to the remaining body tissues. This is demonstrated by the ratio of metal concentrations in the kidney to remaining tissues (mean $\pm S . E$. derived from all samples): $\mathrm{Pb}=27 \pm 3$; $\mathrm{Zn}=22 \pm 2 ; \mathrm{Cd}=13 \pm 2 ; \mathrm{Cu}=4 \pm 0.3$ and $\mathrm{Fe}=2$ \pm 0.2 .

As a result of the very high concentration of $\mathrm{Pb}, \mathrm{Zn}$ and $\mathrm{Cd}$ in the kidney tissues a large proportion of the total body content was found in this tissue, in spite of its relatively small size $(5 \% \pm 0.23$ of total body weight). The proportion of total body content occurring in the kidney tissue was as follows (mean derived from all samples): $\mathrm{Pb}, 58 \% ; \mathrm{Zn}, 50 \%$; Cd, $40 \% ; \mathrm{Cu}, 19 \%$; Fe, $9 \%$.

Population differences. There were population/ environmental differences in the tissue concentrations of $\mathrm{Fe}, \mathrm{Zn}, \mathrm{Pb}, \mathrm{Cu}$ and $\mathrm{Cd}$, but these differences were not apparent in both tissues (Table 3 ). For example, $\mathrm{Pb}$ and $\mathrm{Cu}$ concentrations in the 'remaining tissues' of both native groups of mussels were similar, but the kidney tissues showed population differences; the $\mathrm{Cu}$ concentration in the kidney of SN averaged 1.7 times more than that in TN mussels (Table 3), and at the beginning of the study the $\mathrm{Pb}$ concentration in the kidney tissue of TN was 2-fold higher than the SN mussels (Fig. 10). Population differences were apparent in both kidney and remaining tissues for $\mathrm{Cd}$ (SN > $\mathrm{TN}), \mathrm{Fe}(\mathrm{TN}>\mathrm{SN})$ and $\mathrm{Zn}(\mathrm{SN}>\mathrm{TN})$.

Changes following transplantation. Where there were marked differences between tissue metal concentrations of Tamar and Swansea natives, not all metal concentrations in the tissues of transplanted mussels showed accumulation or depuration towards the native mussels at each site during the 6 mo transplant period. The results revealed that some metals were more biologically labile than others. For example, $\mathrm{Pb}$ was rapidly accumulated and depurated by the kidneys of mussels transplanted to the Tamar and Swansea respectively (Fig. 10). The biological halftime $\left(\mathrm{Tb}_{1 / 2}\right)$ for the decline in $\mathrm{Pb}$ concentration in the kidney of mussels transplanted from the Tamar to Swansea was $<25 \mathrm{~d}$. Fe in the kidney, although at a concentration more than 3-fold higher in the TN compared with the $\mathrm{SN}$, was accumulated $(\mathrm{S} \rightarrow \mathrm{T})$ and lost $(\mathrm{T} \rightarrow \mathrm{S})$ more slowly than $\mathrm{Pb}$ following transplantation (Fig. 11). The $\mathrm{Tb}_{\frac{1}{2}}$ for $\mathrm{Fe}$ in the kidney was 50 to $60 \mathrm{~d}$;

Table 2. Mytilus edulis. Effect of reciprocal transplant of mussels between Tamar estuary and Swansea docks on mean net growth efficiency $[\%)$

\begin{tabular}{|ccccrr|}
\hline Time (weeks) & Dates & Tamar natives & $T \rightarrow$ S transplants & Swansea natives & $S \rightarrow T$ transplants \\
\hline 0 & 9 Jan-11 Jan & $65 \%$ & - & $21 \%$ & - \\
7 & 28 Feb- 5 Mar & $78 \%$ & $46 \%$ & $18 \%$ & $75 \%$ \\
16 & 28 Apr-4 May & $32 \%$ & $83 \%$ & $76 \%$ & $-45 \%$ \\
23 & 15 Jun-18 Jun & $62 \%$ & $25 \%$ & $-6 \%$ & $47 \%$ \\
\hline
\end{tabular}


Table 3. Mytilus edulis. Average metal concentrations in tissues of mussels from Tamar estuary and Swansea docks. TN Tamar natives; SN Swansea natives; $\mathrm{T} \rightarrow \mathrm{S}$ Tamar mussels transplanted to Swansea; $\mathrm{S} \rightarrow \mathrm{T}$ Swansea mussels transplanted to Tamar. Mean \pm S.E.; $n=6$; results from all sampling times combined

\begin{tabular}{|crcccc}
\hline & \multicolumn{2}{c}{ (A) REMAINING TISSUE (Soft body tissues less kidney) $\mu \mathrm{g} \mathrm{g}^{-1} \mathrm{dry}$ mass for 'lg individual' } \\
Sample & $\mathrm{Cd}$ & $\mathrm{Cu}$ & $\mathrm{Fe}$ & $\mathrm{Pb}$ & $\mathrm{Zn}$ \\
\hline $\mathrm{TN}$ & $4.1 \pm 0.4$ & $13.7 \pm 1.4$ & $256 \pm 31$ & $15.8 \pm 2.3$ & $120 \pm 17$ \\
$\mathrm{~T} \rightarrow \mathrm{S}$ & $3.5 \pm 0.4$ & $12.5 \pm 0.9$ & $187 \pm 7$ & $12.7 \pm 1.6$ & $166 \pm 22$ \\
$\mathrm{~S} \rightarrow \mathrm{T}$ & $10.5 \pm 1.2$ & $13.4 \pm 0.6$ & $257 \pm 37$ & $21.7 \pm 3.3$ & $184 \pm 17$ \\
$\mathrm{SN}$ & $7.7 \pm 0.6$ & $12.7 \pm 0.4$ & $164 \pm 9$ & $18.4 \pm 2.4$ & $246 \pm 30$ \\
\hline
\end{tabular}

(B) KIDNEY $\mu \mathrm{g} \mathrm{g}^{-1}$ dry mass for 'lg individual'

\begin{tabular}{lrrrrrr}
\hline Sample & \multicolumn{2}{c}{$\mathrm{Cd}$} & $\mathrm{Cu}$ & $\mathrm{Fe}$ & $\mathrm{Pb}$ & $\mathrm{Zn}$ \\
\hline $\mathrm{TN}$ & $48 \pm 10$ & $42 \pm 5$ & $762 \pm 102$ & $574 \pm 156$ & $2662 \pm 804$ \\
$\mathrm{~T} \rightarrow \mathrm{S}$ & $35 \pm 5$ & $47 \pm 6$ & $383 \pm 63$ & $300 \pm 42$ & $2796 \pm$ \\
$\mathrm{S} \rightarrow \mathrm{T}$ & $132 \pm 3$ & $61 \pm 7$ & $336 \pm 47$ & $610 \pm 111$ & $4216 \pm 1810$ \\
$\mathrm{SN}$ & $75 \pm 9$ & $70 \pm 13$ & $198 \pm 27$ & $342 \pm 48$ & $5371 \pm 440$ \\
\end{tabular}

consequently only a partial accumulation and depuration of Fe was recorded after a 6 mo transplant. In contrast to other metals, the difference between the $\mathrm{Cd}$ concentration in mussels from SN to TN, in both kidney (Fig. 12) and remaining tissues was maintained (SN) or increased $(\mathrm{S} \rightarrow \mathrm{T}$ ) throughout the experimental period in spite of a gradual decline in Cd concentration in the SN and TN, and no equilibration with the new environment was observed. Lack of depuration of $\mathrm{Cd}$ has also been observed in Crassostrea virginica (Greig and Wenzloff, 1978; Zaroogian, 1979); it has been suggested that this may be due to a combination of a slow excretion rate and binding to proteins in the

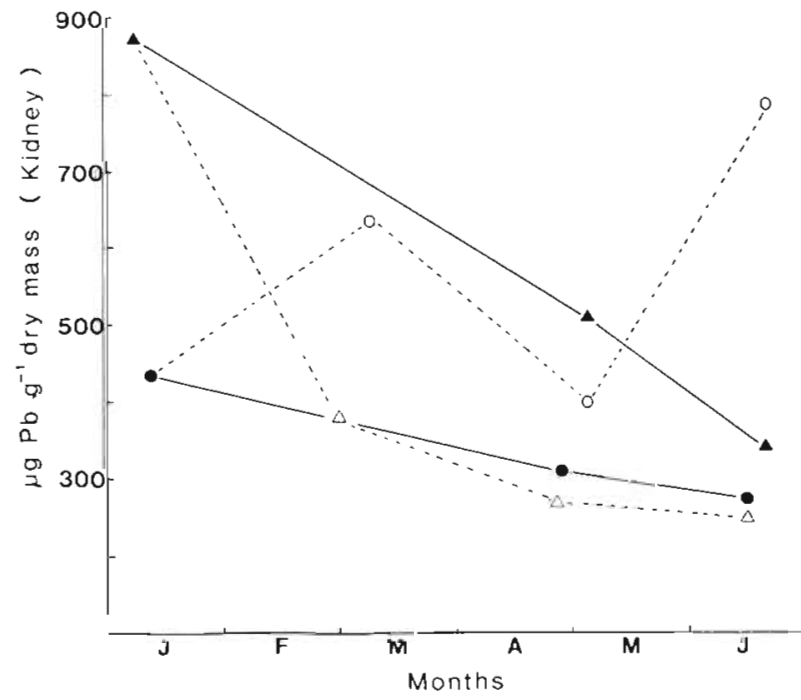

Fig. 10. Mytilus edulis. $\mathrm{Pb}$ concentration ( $\mu \mathrm{g} \mathrm{g}^{-1} \mathrm{dry}$ mass) in kidneys of native and transplanted mussels. $\Delta$ Tamar natives; $\triangle$ Tamar $\rightarrow$ Swansea transplants; - Swansea natives; 0 Swansea $\rightarrow$ Tamar transplants

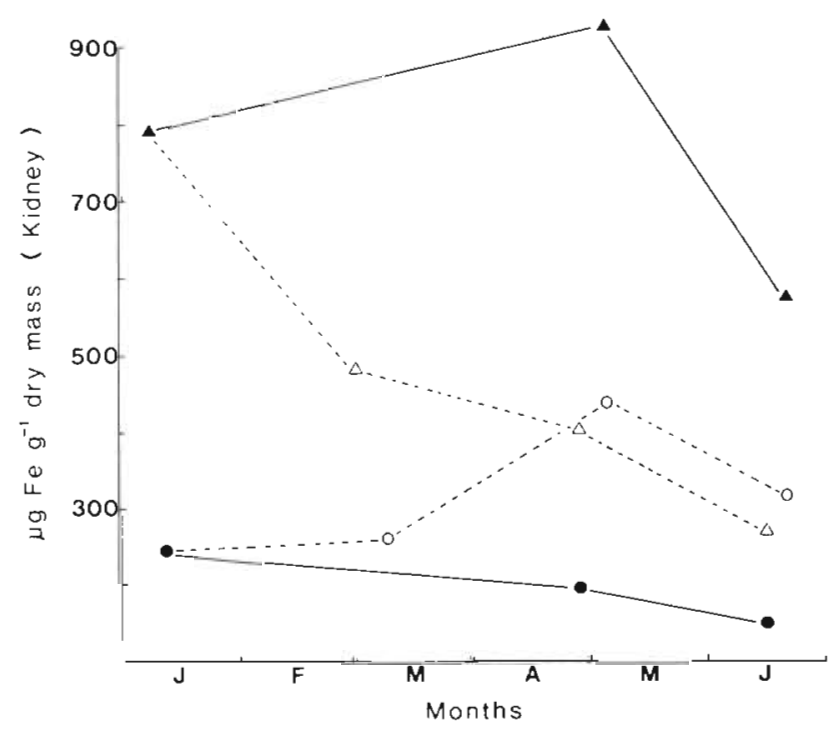

Fig. 11. Mytilus edulis. Fe concentration ( $\mu \mathrm{g} \mathrm{g}^{-1}$ dry mass) in kidneys of native and transplanted mussels. $\Delta$ Tamar natives; $\Delta$ Tamar $\rightarrow$ Swansea transplants; - Swansea natives; 0 Swansea $\rightarrow$ Tamar transplants

tissues (George and Coombs, 1977; Jennings et al., 1979; Zaroogian, 1979).

Tissue hydrocarbon concentrations

Nature of hydrocarbons. The hydrocarbon concentrations in mussels (total tissue) from native and transplanted groups at each site are summarized in Table 4. Hydrocarbon concentrations are presented as $\mathrm{mg} \mathrm{g}^{-1}$ lipid, so that any observed differences are independent of lipid concentration.

After alumina clean-up, steam distillates from both 


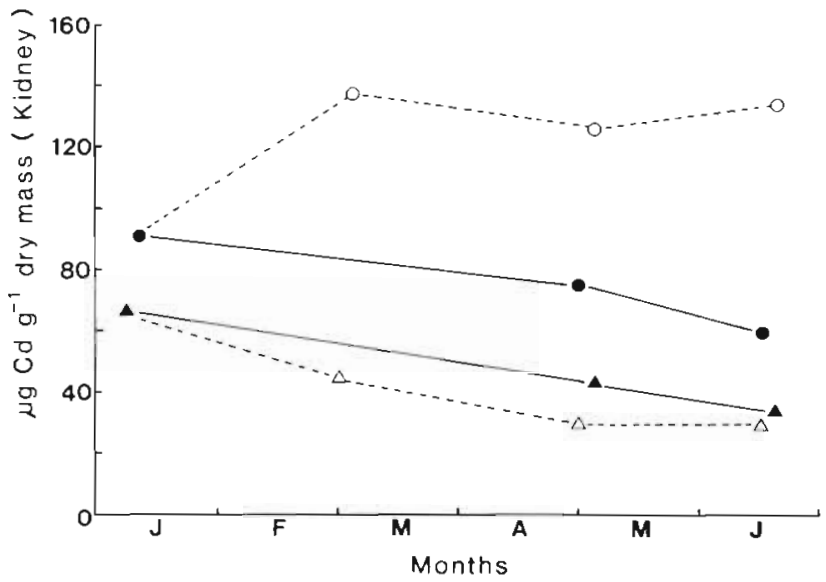

Fig. 12. Mytilus edulis. Cd concentration ( $\mu \mathrm{g} \mathrm{g}^{-1} \mathrm{dry}$ mass) in kidneys of native and transplanted mussels. $\triangle$ Tamar natives; $\triangle$ Tamar $\rightarrow$ Swansea transplants; - Swansea natives; o Swansea $\rightarrow$ Tamar transplants

sites had UV absorbance spectra with a major peak at 229 to $232 \mathrm{~nm}$ and a minor peak at $256 \mathrm{~nm}$, typical of many environmental residues of petroleum products (Levy, 1972; Hennig, 1979). Further evidence that the distillates had a petroleum-like hydrocarbon composition was: (a) close correlation ( $r=0.926)$ between results derived from analysis by UV absorbance at the absorbance maximum of naphthalene (Table 4) and analysis of the same samples by fluorescence at wavelengths most sensitive to 3 and 4 ringed aromatics; (b) similarity of the fluorescence spectra to that of No. 2 fuel oil or oils rich in low molecular weight aromatics (Gordon and Keizer, 1974); (c) presence of HPLC chromatographic peaks at the retention times of naphthalenes, dibenzothiophenes/fluorenes and phenanthrenes; these peaks quantitatively correlated with the UV absorbance data, $\mathrm{r}=0.95$ for naphthalenes and dibenzothiophenes/fluorenes ( $n=10)$, and $0.86(n=7)$ for phenanthrenes; (d) presence of an unresolved envelope in gas chromatograms of the dis- tillates. The size of the unresolved envelope in gas chromatograms is a good quantitative indicator of petroleum derived pollution (Zsolnay, 1978). Hydrocarbon concentrations for 5 mussel tissue extracts calculated from the unresolved envelope, correlated well ( $\mathrm{r}$ $=0.98$ ) with the results obtained for the same samples using UV absorbance (Table 4). It is likely that the observed residue at both sites derived from a combination of direct petroleum inputs (e.g. ship fuel oils) and urban runoff of petroleum and the combustion products of petroleum and coal (Mix and Schaffer, 1979). Coal shipped via Swansea Dock was a further source of hydrocarbons at this site.

Mussels from both resident populations showed a decline in tissue hydrocarbon concentration from January to June. Similar seasonal cycles in the hydrocarbon content of bivalves have been attributed to a combination of intrinsic biological processes such as metabolism and gametogenic activity and higher environmental concentrations of hydrocarbons during the winter caused by increased inputs and lower rates of photooxidation and biodegradation (Dunn and Stich, 1976; Mix and Schaffer, 1979; Burns and Smith, 1981; Mix et al., 1981).

Population differences. At the beginning of the transplant experiment the hydrocarbon concentrations in the mussels from the 2 environments were markedly different; concentrations in Swansea natives were 3fold higher than in Tamar native mussels (Table 4). Transplanted mussels ( $\mathrm{T} \rightarrow \mathrm{S}$ ) accumulated and $(\mathrm{S} \rightarrow \mathrm{T})$ depurated hydrocarbons relatively slowly. The $\mathrm{T} \rightarrow \mathrm{S}$ mussels accumulated hydrocarbons and reached a maximum tissue concentration after 4 mo in the new environment, but then declined in the same manner as the Swansea natives. Similarly, the $S \rightarrow T$ mussels required up to 4 mo to depurate the accumulated hydrocarbons at the Tamar site. The high concentration of hydrocarbons in the tissues of $\mathrm{T} \rightarrow \mathrm{S}$ mussels during the spring (Week 16) was probably due to the

Table 4. Mytilus edulis. Hydrocarbon concentrations in tissue; mg hydrocarbon (expressed as North Sea crude oil equivalents $\left.{ }^{*}\right)$ $\mathrm{g}^{-1}$ lipid. NA: Not analysed

\begin{tabular}{|c|c|c|c|c|c|}
\hline Time (week) & $\begin{array}{c}\text { Date of collection } \\
(1978)\end{array}$ & Tamar natives & $\begin{array}{c}\text { Tamar to Swansea } \\
\text { transplants }\end{array}$ & Swansea natives & $\begin{array}{c}\text { Swansea to Tamar } \\
\text { transplants }\end{array}$ \\
\hline 0 & 9 Jan-11 Jan & $17.5^{\circ}$ & 17.5 & $50.8^{*}$ & 50.8 \\
\hline 7 & $28 \mathrm{Feb}-5 \mathrm{Mar}$ & 14.3 & 23.8 & NA & 40.6 \\
\hline 16 & 28 Apr- 4 May & 17.1 & 49.4 & 24.5 & 16.2 \\
\hline 23 & 15 Jun-18 Jun & 11.6 & 18.9 & 19.0 & 13.5 \\
\hline \multicolumn{6}{|c|}{$\begin{array}{l}\text { Auk field crude oil. An oil concentration of } 47 \mu \mathrm{g} \mathrm{ml}^{-1} \text { had an absorbance equivalent to a naphthalene concentration of } 1 \mu \mathrm{g} \\
\mathrm{ml}^{-1} \text { (read at } 221 \mathrm{~nm} \text { in hexane). Mussels from a rural open coast site had hydrocarbon concentrations of ca. } 1.0 \mathrm{mg} \mathrm{g}^{-1} \text { lipid } \\
\text { when analysed by this procedure. Replicate hydrocarbon analyses of homogeneous samples fell within the range } \pm 10 \% \text {. } \\
\cdots \text { Two samples (TN and SN, Jan } 78 \text { ) were analysed (in duplicate) by both GLC and UV spectrophotometry. Total } \\
\text { hydrocarbon concentrations determined by GLC were } 77 \% \text { and } 68 \% \text { of those determined by UV spectrophotometry for TN } \\
\text { and SN respectively. Aromatic hydrocarbons formed }-38 \% \text { of the total hydrocarbons }\end{array}$} \\
\hline
\end{tabular}


more marked and synchronized reproductive cycle in this group of mussels. There was a large amount of ripe gamete material in the mantle, consequently hydrocarbons were accumulated rapidly and their turn over was slower.

\section{DISCUSSION}

Field measurement of mussels living in 2 different environments - Tamar estuary and Swansea docks showed that the 2 populations of Mytilus edulis were markedly different both in morphological characteristics and in physiological responses (clearance rate, absorption efficiency, respiration, excretion rate, $\mathrm{O}: \mathrm{N}$, scope for growth). Reciprocal transplantation of mussels between populations was used to examine the phenotypic plasticity of the physiological responses. The acclimatization of transplanted mussels to their new environments within 2 mo demonstrated that the measured physiological differences between populations were largely a function of environmental conditions.

However, acclimatization was not complete. Values for clearance rate, scope for growth and growth efficiency of mussels originating from the Tamar (TN and $\mathrm{T} \rightarrow \mathrm{S}$ ) were consistently higher than values for mussels originating from Swansea ( $\mathrm{SN}$ and $\mathrm{S} \rightarrow \mathrm{T}$ ). The differences in scope for growth and growth efficiency between the native and transplanted mussels at a particular site were due, in part, to the differences in clearance rate (Fig. 5). The clearance rate of transplants changed by approximately $75 \%$ of the difference between the clearance rates of the native populations. This $75 \%$ change may be ascribed to the environmental characteristics of the 2 sites. The existence of a residual difference in clearance rate and in scope for growth and growth efficiency suggests that there may be further acclimatization to the prevailing environmental conditions which takes longer than 6 mo and/or that the slight physiological differences may reflect genetic differences between the 2 mussel populations.

Levinton and Koehn (1976) provided evidence of considerable genetic variability in populations of Mytilus edulis. In a study of the geographic variation at 2 diagnostic allozyme loci in mussels, Skibinski et al., (1978) and Skibinski and Beardmore (1979) showed considerable spatial variation both in allele frequencies and in the extent of intergradation. They found that Tamar mussels conformed to the $M$. edulis genotype and Swansea dock mussels were intermediate between the $M$. edulis and $M$. galloprovincialis genotypes with high levels of genetic mixing. A substantial amount of the phenotypic growth variation in young mussels is a result of genetic differences within a population (Innes and Haley, 1977; Freeman and Dickie, 1979). Singh and Zouros (1978) and Zouros et al. (1980) demonstrated that the growth rate of oysters Crassostrea virginica were greater among individuals with more enzyme heterozygosity. Koehn and Shumway (1982) have since provided a physiological explanation by demonstrating a lower rate of oxygen consumption in individuals with a higher growth rate and a higher level of enzyme heterozygosity. The present study shows that the population differences in physiological response are largely determined by environmental factors and that a smaller proportion ( $\sim 25 \%$ of the difference in clearance rate) may be attributable to genetic differences.

We have measured a number of environmental factors which have the potential to influence physiological condition. Of these, the differences in temperature and salinity between the 2 sites were so small that they were unlikely to account for the observed biological effects. Suspended particulate material was present at higher concentrations at the Tamar site than at Swansea throughout most of the study period. However, high seston concentrations normally give rise to reduced clearance rates (Schulte, 1975; Widdows et al., 1979; Kiorboe et al., 1980), whereas the clearance rates of Tamar mussels were consistently higher than those of Swansea mussels. The only clear effect of quality and quantity of particulate material on the physiological measurements was the transient increase in scope for growth at Swansea measured during the spring algal bloom and the simultaneous low scope for growth determined in Tamar mussels due to a transient drop in seston concentration. On all other occasions, higher estimates of scope for growth and growth efficiencies were recorded in mussels (native and transplanted) living in the Tamar. Thus, differences in the major natural environmental stressors could not account for the very low clearance rates and reduced scope for growth recorded in Swansea natives and Tamar $\rightarrow$ Swansea transplants. This suggests that anthropogenic stressors acting singly or in combination may be the cause of the observed biological effects.

An indication of the environmental quality of the Tamar and Swansea dock sites in terms of metals may be obtained by comparing our mussel tissue data with those published by Boyden (1977), Goldberg et al. (1978) and Davies and Pirie (1980). Both TN and SN had relatively low copper concentrations similar to mussels from 'clean' environments, and Fe concentrations were within the range reported for the US Mussel Watch (Goldberg et al., 1978). Lead concentrations in the tissues of TN and SN mussels were equal to those concentrations found in the 'contaminated' mussels from Restronguet Creek in Comwall (Boyden, 1977), but were generally higher than the $\mathrm{Pb}$ concentrations 
in mussels sampled as part of the US and Scottish 'Mussel Watch' projects (Goldberg et al., 1978; Davies and Pirie, 1980). The $\mathrm{Zn}$ concentrations in the SN mussels were slightly higher than the Zn concentrations in mussels from a 'contaminated' environment (Restronguet Creek; Boyden, 1977) and were comparable with the highest levels detemined in the US and Scottish Mussel Watch programmes. Cadmium concentrations in the Tamar mussels were similar to the concentrations in Mytilus edulis from a 'clean' site (Menai Strait; Boyden, 1977), whereas the SN were intermediate between the values for mussels from 'clean' and 'contaminated' (Inner harbour, Poole; Boyden, 1977) environments and were comparable to the upper values for $\mathrm{Cd}$ concentrations found in the US and Scottish 'Mussel Watch' projects.

Therefore, both sites could be considered to be contaminated to some extent, with Swansea dock being the poorer environment of the two. Nevertheless, there is no clear evidence that the tissue concentrations of any of the metals determined in this study were toxic to Mytilus edulis, or that the changes in metal concentrations in the whole mussel which resulted from transplantation could account for the biological effects recorded, particularly the relatively rapid recovery of the $\mathrm{S} \rightarrow \mathrm{T}$ mussels.

The results from laboratory studies generally support this conclusion. For example, Strömgren (1982) determined the exposure concentrations of metals which resulted in a $50 \%$ reduction in the shell growth $\left(\mathrm{EC}_{50}\right)$ of Mytilus edulis after 10 to $22 \mathrm{~d}$. The $\mathrm{EC}_{50}$ values were

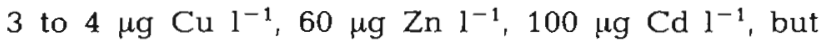
$>200 \mu \mathrm{g} \mathrm{l}^{-1}$ of $\mathrm{Pb}$ and $\mathrm{Zn}$ had no effect on shell growth. Metal concentrations in the lower Tamar are $\sim 1 \mu \mathrm{g} \mathrm{Cu} \mathrm{l}^{-1},<0.5 \mu \mathrm{g} \mathrm{Cd} \mathrm{1}^{-1}, \sim 0.5 \mu \mathrm{g} \mathrm{Fe} 1^{-1}$ and $\sim 8$ $\mu \mathrm{g} \mathrm{Zn} 1^{-1}$ (Stebbing et al., 1983). If it is assumed that the higher concentrations of $\mathrm{Cd}$ and $\mathrm{Zn}$ in the tissues of Swansea mussels reflects a proportionately (2-fold) higher metal concentration in the water at this site, then these concentrations $\left(\sim 1 \mu \mathrm{g} \mathrm{Cd}^{-1}\right.$ and $\sim 16 \mu \mathrm{g}$ $\mathrm{Zn} \mathbf{l}^{-1}$ ) are well below the $\mathrm{EC}_{50}$ values recorded by Strömgren (1982).

Myint and Tyler (1982) examined the effects of $98 \mathrm{~d}$ of exposure to $\mathrm{Cu}, \mathrm{Cd}$ and $\mathrm{Zn}$ (initial exposure concentrations 50,50 and $200 \mu \mathrm{g} 1^{-1}$ respectively) on the gametogenesis of Mytilus edulis collected from Mumbles, Swansea Bay. They observed suppression of gametogenesis and vitellogenesis, and ultimately mortality ( $\mathrm{LC}_{50}$ of $84 \mathrm{~d}$ ), associated with tissue $\mathrm{Cu}$ concentrations 2 to 3 times higher than those measured in the Swansea and Tamar mussels. There was also a slight inhibition of gametogenesis at $\mathrm{Zn}$ tissue concentrations comparable to those found in Swansea dock mussels. Cd was the least toxic and had little effect at tissue concentrations 10 times higher than those recorded in the Swansea native mussels. Similarly, Poulsen et al. (1982) found that body loads up to $150 \mu \mathrm{g}$

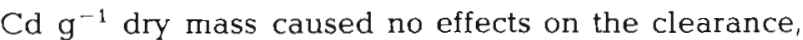
ingestion, food absorption, respiration and growth of $M$. edulis. In the present field study, no marked inhibition of gametogenesis was observed in either the $\mathrm{SN}$ or $\mathrm{T} \rightarrow \mathrm{S}$ mussels. The effect of $\mathrm{Cu}$ and $\mathrm{Zn}$ on the gametogenic development of $M$. edulis (Myint and Tyler, 1982) may therefore have been a function of the laboratory exposure conditions; their mussels were unfed and held in tanks of aerated artificial seawater and under these conditions the toxic effects of $\mathrm{Cu}$ and Zn may have been enhanced.

Low concentrations of petroleum hydrocarbons had, both in field and laboratory investigations, adverse effects on the feeding, respiration, excretion and growth of bivalve molluscs (Gilfillan et al., 1977; Bayne et al., 1982; Widdows et al., 1982). Furthermore, these studies have shown a significant negative correlation between tissue aromatic hydrocarbon concentration and biological responses such as scope for growth. If the elevated levels of petroleum-derived hydrocarbons detected in the tissues of mussels sampled from Swansea dock were responsible, at least in part, for the observed biological effects such as reduced clearance rate and scope for growth, then there was no simple correlation between clearance rate or scope for growth and tissue hydrocarbon concentrations following reciprocal transplantation.

This lack of agreement may have been due to differences in the timecourse of response. The rate of accumulation and the hydrocarbon concentration in mussel tissues is related not only to the hydrocarbon concentration in the water but also to the amount of water pumped through the mantle cavity by the gills (Clement et al., 1980; Widdows, unpubl.). Mussels transplanted from Tamar to Swansea reduced their clearance rate (= ventilation rate) within 2 mo (Fig. 5), possibly in direct response to the hydrocarbon concentration in the water or the concentration in the gills following rapid accumulation by this tissue (Riley et al., 1981), and thereby reduced both the amount of hydrocarbons made available to the body tissues and the rate of uptake.

Mussels transplanted from Swansea to Tamar showed a slow rate of depuration in spite of the rapid increase in clearance/ventilation rate. Bivalves chronically exposed to oil usually fail to return rapidly to pre-exposure hydrocarbon levels during depuration (Boehm and Quinn, 1977; Blackman and Law, 1980; Clement et al., 1980). Stegeman and Teal (1973) suggested a stable compartment in an organism which, after saturation with hydrocarbons, released those hydrocarbons very slowly. The lipid concentration which generally reaches a maximum in the spring at the time 
of active gametogenesis (Zurburg et al., 1979), varied in our study between $6.85 \%$ and $9.81 \%$ of the dry body weight. Hydrocarbons accumulated in the lipid reserves of gametes during gametogenesis in late winter/early spring, may be lost very slowly when mussels are transferred to a 'cleaner' environment and yet may be toxicologically inactive towards the parent organism. Recent studies (Widdows, unpubl.) have shown that the clearance rate and other physiological responses of Mytilus edulis are capable of rapid recovery, in terms of days or weeks, following a period of chronic exposure to petroleum hydrocarbons. Consequently, a simple correlation between dose $(=$ tissue aromatic hydrocarbon concentration) and response (= clearance rate) will not be apparent under conditions of rapid recovery and slow depuration.

This study illustrates the difficulty of identifying the cause(s) of an observed sublethal biological effect in a field situation where there are numerous identified and unidentified contaminants. A simple correlation between a single contaminant and an effect is perhaps unlikely in a complex situation where several contaminants may be acting in combination. Stebbing et al. (1984) recently highlighted a similar problem of establishing the cause of a bioassay response to water samples from the Tamar estuary. In future studies a wider range of environmental contaminants needs to be measured including, for example, halogenated hydrocarbons and organo-tin compounds. In addition, it is necessary to obtain more information on the relative toxicity, measured in terms of sublethal biological effects, of environmental contaminants to indicator organisms' such as mussels.

Although the present study has been unable to identify clearly the cause of the biological effects reported, it has demonstrated a considerable sensitivity of physiological responses to prevailing environmental conditions; the time-course of acclimatization by transplanted mussels $(<2 \mathrm{mo}$ ) indicates a plasticity of such responses similar to that observed in laboratory studies. These findings lend confidence to the use of physiological data to measure the effects of environmental stressors including pollutants.

Acknowledgements. We thank Dr. B. L. Bayne for helpful discussions and for critically reading the manuscript. We are also grateful to D. R. Dixon for assistance. This work forms part of the experimental ecology programme of the Institute for Marine Environmental Research, a component of the Natural Environment Research Council. It was commissioned in part by the Commission of the European Communities (Contract Nos. 279-77-4 ENV U. K. and 329-77-4 ENV U. K.), and by the Department of the Environment (Contract No. DGR 480/683).

\section{LITERATURE CITED}

Bayne, B. L. (1973). Physiological changes in Mytilus edulis L. induced by temperature and nutritive stress. $J$. mar. biol. A.ss. U. K. 53: 39-58

Bayne, B. L., Moore, M. N., Widdows, J., Livingstone, D. R., Salkeld, P. N. (1979). Measurement of the responses of individuals to environmental stress and pollution: studies with bivalve molluscs. Phil. Trans. R. Soc. (Ser. B) 286: 563-581

Bayne, B. L., Thompson, R. J., Widdows, J. (1976a). Physiology I. In: Bayne, B. L. (ed.) Marine mussels Cambridge University Press, Cambridge, p. 121-206

Bayne, B. L., Widdows, J. (1978). Physiological ecology of two populations of Mytilus edulis L. Oecologia 37: 137-162

Bayne, B. L., Widdows, J., Moore, M. N., Salkeld, P. N., Worrall, C. M., Donkin, P. (1982). Some ecological consequences of the physiological and biochemical effects of petroleum compounds on marine molluscs. Phil. Trans. R. Soc. Lond. B. 297: 219-239

Bayne, B. L., Widdows, J., Newell, R. I. E. (1977). Physiological measurements on estuarine bivalve molluscs in the field. In: Keegan, B. F., O'Ceidigh, P., Boaden, P. J. S. (ed.) Biology of benthic organisms. Pergamon Press, New York, p. $57-68$

Bayne, B. L., Widdows, J., Thompson, R. J. (1976b). Physiological integrations. In: Bayne, B. L. (ed.) Marine mussels. Cambridge University Press, Cambridge, p. 261-291

Blackman, R. A. A., Law, R. J. (1980). The Eleni V oil spill: fate and effects of the oil over the first twelve months. Mar. Pollut. Bull. 11: 217-220

Bligh, E. G., Dyer, W. J. (1959). A rapid method of total lipid extraction and purification. Can. J. Biochem. Physiol. 37 : 911-917

Boehm, P. D., Quinn, J. G. (1977). The persistence of chronically accumulated hydrocarbons in the hard shell clam Mercenaria mercenaria. Mar. Biol. 44: 227-233

Boyden, C. R. (1977). Effect of size upon metal content of shellfish. J. mar. biol. Ass. U. K. 57: 675-714

Burns, K. A., Smith, J. L. (1981). Biological monitoring of ambient water quality: the case for using bivalves as sentinel organisms for monitoring petroleum pollution in coastal waters. Estuar. coast. Shelf Sci. 13: 433-443

Clement, L. E., Stekoll, M. S., Shaw, D G. (1980). Accumulation, fractionation and release of oil by the intertidal clam Macoma balthica. Mar. Biol. 57: 41-50

Conover, R. J. (1966). Assimilation of organic matter by zooplankton. Limnol. Oceanogr. 11: 338-354

Corner, E. D. S., Cowey, C. B. (1968). Biochemical studies on the production of marine zooplankton. Biol. Rev. 43: 393-426

Davies, I. M., Pirie, J. M. (1980). Evaluation of a 'Mussel Watch' project for heavy metals in Scottish coastal waters. Mar. Biol. 57: 87-93

Dunn, B. P., Stich, H. F. (1976). Monitoring procedures for chemical carcinogens in coastal waters. J. Fish. Res. Bd Can. 33: 2040-2046

Freeman, K. R., Dickie, L. M. (1979). Growth and mortality of the blue mussel (Mytilus edulis) in relation to environmental indexing. J. Fish. Res. Bd Can. 36: 1238-1249

George, S. G., Coombs, T. L. (1977). The effects of chelating agents on the uptake and accumulation of cadmium by Mytilus edulis. Mar. Biol. 39: 261-268

Gilfillan, E. S., Mayo, D. W., Page, D. S., Donovan, D., Hanson, S. (1977). Effects of varying concentrations of petroleum hydrocarbons in sediments on carbon flux in Mya arenaria. In: Vemberg, F. J., Calabrese, A., Thurberg, F. 
P., Vernberg, W. B. (ed.) Physiological responses of marine biota to pollutants. Academic Press, New York, p. 299-314

Goldberg, E. D., Bowen, V. T., Farrington, J. W., Harvey, G. Martin, J. H., Parker, P. L., Riseborough, R. W., Robertson, W., Schneider, E. D., Gamble, E. (1978). The mussel watch. Environ. Conserv. 5: 101-125

Gordon, D. C., Keizer, P. D. (1974). Estimation of petroleum hydrocarbons in seawater by fluorescence spectroscopy: improved sampling and analytical methods. Department of the Environment (Canada), Fisheries and Marine Service, Marine Ecology Laboratory, Technical Report No. 481

Gordon, D. C., Keizer, P. D., Dale, J. (1974). Estimates using fluorescence spectroscopy of the present state of petroleum hydrocarbon contamination in the water column of the northwest Atlantic ocean. Mar. Chem. 2: 251-261

Greig, R. A., Wenzloff, D. R. (1978). Metal accumulation and depuration by the American oyster, Crassostrea virginica. Bull. environ. Contam. Toxicol. 20: 499-504

Hennig, H. F.-K. O. (1979). Quantitative analysis of residual fuel oil in sediment samples by absorption spectrophotometry. Mar. Pollut. Bull. 10: 234-237

Innes, D. J., Haley, L. E. (1977). Genetic aspects of larval growth under reduced salinity in Mytilus edulis. Biol. Bull. mar. biol. Lab., Woods Hole 153: 312-321

Jennings, J. R., Rainbow, P. S., Scott, A. G. (1979). Studies on the uptake of cadmium by the crab Carcinus maenas in the laboratory. II Preliminary investigation of cadmiumbinding proteins. Mar. Biol. 50: 141-149

Kiorboe, T., Møhlenberg, F., Nøhr, D. (1980). Feeding, particle selection and carbon absorption in Mytilus edulis in different mixtures of algae and resuspended bottom material. Ophelia 19: 193-205

Koehn, R. K. (1978). Biochemical aspects of genetic variation at the Lap locus in Mytilus edulis. In: Battaglia, B., Beardmore, J. A. (ed.) Marine organisms: genetics, ecology and evolution. Plenum Press, New York, p. 211-227

Koehn, R. K., Shumway, S. E. (1982). A genetic physiological explanation for differential growth rate among individuals of the American oyster Crassostrea virginica (Gmelin). Mar. Biol, Lett. 3: 35-42

Levinton, J. S., Koehn, R. K. (1976). Population genetics of mussels. In: Bayne, B. L. (ed.) Marine mussels. Cambridge University Press, Cambridge, p. 357-384

Levy, E. M. (1972). The identification of petroleum products in the marine environment by absorption spectrophotometry. Wat. Res. 6: 57-69

Lowe, D. M., Moore, M. N., Bayne, B. L. (1982). Aspects of gametogenesis in the marine mussel Mytilus edulis. J. mar. biol. Ass. U. K. 62: 125-132

Mix, M. C., Schaffer, R. L. (1979). Benzo(a)pyrene concentrations in mussels (Mytilus edulis) from Yaquina bay, Oregon during June 1976 - May 1978. Bull, environ. Contam. Toxicol. 23: 677-684

Mix, M. C., Schaffer, R. L., Hemingway, S. J. (1981). Polynuclear aromatic hydrocarbons in bay mussels (Mytilus edulis) from Oregon. In: Daure,C. J., Harshbarger, J. C., Konde, S., Sugimura, T., Takayama S. (ed.) Phytelic approaches to cancer. Japan Scientific Societies Press, Tokyo, p. $167-177$

Myint, U. M., Tyler, P. A. (1982). Effects of temperature, nutritive and metal stressors on the reproductive biology of Mytilus edulis. Mar. Biol. 67: 209-223

Neff, J. M., Anderson, J. W. (1975). An ultraviolet spectrophotometric method for the determination of naphthalene and alkylnaphthalenes in the tissues of oil-con- taminated marine animals. Bull. environ. Contam. Toxicol. 14: $122-128$

Phillips, D. J. H. (1980). Quantitative aquatic biological indicators. Applied Science Publishers, London

Poulsen, E., Riisgård, H. U., Møhlenberg, F. (1982). Accumulation of cadmium and bioenergetics in the mussel Mytilus edulis. Mar. Biol. 68: 25-29

Riley, R. T., Mix, M. C., Schaffer, R. L., Bunting, D. L. (1981). Uptake and accumulation of naphthalene by the oyster Ostrea edulis, in a flow through system. Mar. Biol. 61: $267-276$

Schulte, E. H. (1975). Influence of algal concentration and temperature on the filtration rate of Mytilus edulis. Mar. Biol. 30: 331-341

Singh, S. M., Zouros, E. (1978). Genetic variation associated with growth rate in the American oyster (Crassostrea virginica). Evolution 32: 342-353

Skibinski, D. O. F., Beardmore, J. A., Ahmad, M. (1978). Genetic aids to the study of closely related taxa of the genus Mytilus. In: Battaglia, B., Beardmore, J. A. (ed.) Marine organisms genetics, ecology and evolution. Pergamon Press, New York, p. 469-486

Skibinski, D. O. F., Beardmore, J. A. (1979). A genetic study of intergradation between Mytilus edulis and $M$. galloprovincialis. Experientia 35: 1442-1444

Solorzano, L. (1969). Determination of ammonia in natural waters by the phenol-hypochlorite method. Limnol. Oceanogr. 14: 799-801

Stebbing, A. R. D., Cleary, J. J., Brown, L., Rhead, M. (1984). The problem of relating toxic effects to their chemical causes in waters receiving wastes and effluents. In: Kilho Park, P. (ed.) Wastes in the ocean, Vol. 10, Monitoring strategies for ocean waste disposal. Wiley Interscience, Chichester (in press)

Stegeman, J. J., Teal, J. M. (1973). Accumulation, release and retention of petroleum hydrocarbons by the oyster Crassostrea virginica. Mar. Biol. 22: $3 \overline{7}-44$

Strömgren, T. (1982). Effects of heavy metals ( $\mathrm{Zn}, \mathrm{Hg}, \mathrm{Cu}, \mathrm{Cd}$, $\mathrm{Pb}, \mathrm{Ni}$ ) on the length growth of Mytilus edulis. Mar. Biol. 72: $69-72$

Warren, C. E., Davis, G. E. (1967). Laboratory studies on the feeding, bioenergetics and growth of fish. In: Gerking, S. D. (ed.) The biological basis of freshwater fish production. Blackwell Scientific Publications, Oxford, p. 175-214

Widdows, J. (1978a). Combined effects of body size, food concentration and season on the physiology of Mytilus edulis. J. mar, biol. Ass. U. K. 58: 109-124

Widdows, J. (1978b). Physiological indices of stress in Mytilus edulis. J. mar. biol. Ass. U. K. 58: 125-142

Widdows, J. (1984). Physiological procedures. In: Bayne, B. L (ed.) Biological effects of stress and pollution in marine animals: ideas and techniques. Praeger Press, New York (in press)

Widdows, J., Bakke, T., Bayne, B. L., Donkin, P., Livingstone, D. R., Moore, M. N., Evans, S. V., Moore, S. L. (1982). Responses of Mytilus edulis on exposure to the wateraccommodated fraction of North Sea oil. Mar. Biol. 67: $15-31$

Widdows, J., Fieth, P., Worrall, C. M. (1979). Relationships between seston, available food and feeding activity in the common mussel Mytilus edulis. Mar. Biol. 50: 195-207

Widdows, J., Phelps, D. K., Galloway, W. (1981). Measurement of physiological condition of mussels transplanted along a pollution gradient in Narragensett Bay. Mar. environ. Res. 4: 181-194

Zaroogian, G. E. (1979). Studies on the depuration of cad- 
mium and copper by the American oyster Crassostrea virginica. Bull. environ. Contam. Toxicol. 23: 117-122

Zitko, V. (1975). Aromatic hydrocarbons in aquatic fauna. Bull. environ. Contam. Toxicol. 14: 621-631

Zouros, E., Singh, S. M., Miles, H. E. (1980). Growth rate in oysters: an overdominant phenotype and its possible explanations. Evolution 34: 856-867

Zsolnay, A. (1978). Lack of correlation between gas-liquid chromatograph and UV absorption indicators of petroleum pollution in organisms. Wat. Air Soil Pollut. 9: 45-51

Zurburg, W., Kluytmans, J. H., Pieters, H., Zandee, D. I. (1979). The influence of seasonal changes on energy metabolism in Mytilus edulis (L.) II. Organ specificity. In: Naylor, E., Hartnoll, R. G. (ed.) Cyclic phenomena in marine plants and animals. Pergamon Press, Oxford, p. 293-300

This paper was submitted to the editor; it was accepted for printing on January 14, 1984 